\title{
DIATHEKEE; VERBOND OF TESTAMENT?
}

In Galate 3, 15-18 skryf die Apostel Paulus: „15. Broeders, ek spreek menslikerwys: selfs ' $n$ mens se te sta me $\mathrm{nt}^{1}$ ) wat bekragtig is, maak niemand tot niet of voeg daaraan toe nie. 16. Nou is aan Abraham die belofte toegesê en aan sy saad. Hy sê nie: En aan die sade, asof dit sien op baie nie, maar op een: En aan jou saad - dit is Christus. 17. Maar ek sê dit - die wet wat vier honderd en dertig jaar later gekom het, maak die ve r bo nd ${ }^{1}$ ) wat deur God in Christus vantevore bekragtig is, nie kragteloos om die belofte tot niet te maak nie. 18. Want as die erfenis uit die wet is, dan is dit nie meer uit die belofte nie. Maar God het dit aan 'Abraham deur 'n belofte genadiglik geskenk."

Waar in die aangehaalde teks in Afrikaans, testament' en ,verbond' gebruik word, staan in die oorspronklike Griekse teks in beide gevalle die woord diathêkê. Testament en verbond is in Afrikaans egter nie identiek nie. Volgens ons hedendaagse regsopvatting is 'n testament 'n eensydige regshandeling, waarby die wil van slegs een persoon, die erflater in die spel is, terwyl 'n verbond ' $n$ tweesydige regshandeling is, wat in wese bestaan in die wilsooreenstemming van twee of meer persone. Daarom word die vraag gestel of daar 'n verklaring is van die gebruik in Grieks van een en dieselfde woord vir twee verskillende begrippe, of dat miskien een van beide vertalings, of beide, minder juis is.

Die woord diathêkê kom in die Nuwe Testament herhaaldelik voor. Dit word ook aangetref in die Griekse vertaling van die Ou Testament. Volgens Kitrel kom dit daar 270 maal voor. ${ }^{2}$ ) Die betekenis wat dit in Grieks het is (1) uiterste wilsbeskikking, testament; (2) ooreenkoms, verdrag (en in hierdie betekenis kom dit ooreen met sunthêkê); (3) verordening, beskikking, bepaling.

In die Septuagint vind ons diathêkê gebruik in profane sin om 'n verhouding van mens tot mens aan te dui, soos bv. in Genesis 31, 44 waar JAKOB en LABAN met mekaar 'n ooreenkoms aangaan ${ }^{3}$ ) en in I Samuel 18, 3, waar Davin en Jónatan 'n ooreenkoms sluit. ${ }^{1}$ ) Daarnaas en in die reël word dit egter gebruik om die verhouding van mens tot God aan te dui. In die sin vind ons diathêkê telkens in die Nuwe

1) spasiëring van die skrywer.

2) G. KITteL, Theologisches Wörterbuch zum Neuen Testament, Bnd. II (1935) bl. 105 e.v.

3) vgl. die ooreenkoms tussen JAKOB en EsAu in Genesis 25, 26-34.

4) vgl. I Samuel 20,$8 ; 23,18$. 
Testament ook gebruik. Die Apostel Paulus gebruik dit, ${ }^{5}$ ) die skrywer van die brief aan die Hebreërs gebruik dit veelvuldig, dit kom voor by die Synoptici waar hulle die instelling van die heilige nagmaal deur Jesus beskryf, ${ }^{6}$ ) dit verskyn in die verslag van die Handelinge van die Apostels ${ }^{7}$ ) en in Openbaring. Die inhoud of wese van die verhouding van mens tot God bestaan dan in die goddelike beloftes wat aan God se menslike deelgenoot Israel gemaak is. ${ }^{8}$ )

Ook elders, nl. in die brief aan die Hebreërs, vertaal die Afrikaanse Bybelvertaling afwisselend deur, verbond' en ,testament'. Die Vulgata gebruik deurgaans ,testamentum', LUTHER vertaal deurgaans met ,Testament', die State-vertaling gee sowel ,verbond' as ,testament', die Authorised Version gebruik ook ,covenant' en ,testament' langs mekaar, die Revised Version wyk op 'n enkele plek hiervan af deur, testament' en ,covenant' te verwissel. Professor Brouwer gebruik in sy vertaling van die Nuwe Testament langs, verbond' die uitdrukkings, rechtskrachtige beschikking'9), rechtskrachtig gemaakte beschikking, ${ }^{10}$ ), hoogere beschikking', 11) ,beschikking', ${ }^{12}$ ) ,uiterste wilsbeschikking', ${ }^{13}$ ) en ,wilsbeschikking'. ${ }^{14}$ ) Die Twentieth Century New Testament gee voorkeur aan die gebruik van , covenant ${ }^{15}$ ) Dit lei die vertalers daartoe om Hebreërs 9, 16 te vertaal met: „Whenever such a Covenant as a will is in question, the death of the testator must of necessity be alleged". Die verband verplig hier tot vertaling van diathêkê met ,testament' of ,uiterste wilsbeskikking', want dit is juis vir die werking in regte van 'n testament vereis dat die dood van die erflater, wie se testament dit is, eers moet intree. Dit kan egter volgens hedendaagse regsopvatting moeilik verantwoord word om 'n testament 'n ,covenant', d.i. 'n ooreenkoms te noem. Dit veronderstel nl. twee partye wat op voet van gelykheid teenoor mekaar staan. Elders, in Galate 3, 15 en 17, vind ons in hierdie Engelse vertaling vir diathêkê, waar in Afrikaans die woorde ,verbond' en ,testament' staan, die woord, agreement' gebruik, wat nog sterker die gedagte van wilsooreenstemming tussen twee of meer partye op voet van gelykheid beklemtoon

Die vraag wat ons hier besig hou is, hoe dit vanuit regsoogpunt beskou, verklaar moet word dat die woord diathêkê in die oorspronklike teks in die verskillende betekenisse wat deur die genoemde vertalings uit-

5) o.a. in Galate 3, 15-18.

') Markus 14, 24; Matthéüs 26, 28; Lukas 22, 20; vgl. I Kor. 11, 25; dit kom ook voor in Lukas 1, 72, vgl. in die verband Psalm 105, 8 en Psalm 106, 45.

7) Handelinge 7,8 .

8) Galate 3, 16; Nock, St. Paul (1938), p. 40.

') Galate 3, 15

10) Galate 3, 17

11) Hebr. 7, 22; 8, 6; 9, 15 .

12) Hebr. 8, 8, 9 en 10 .

12) Hebr. 9, 16.

19) Hebr. 9, 20.

1.5) kyk die vertaling van die brief aan die Hebreërs 7, 8 en 9. 
gedruk word, gebruik kan word. 'n Ondersoek na die wyse waarop regshandelinge tot stand kom, kan moontlik 'n verklaring aan die hand gee. Ons maak daarby by voorkeur gebruik van wat die ou reg en met name die vroeë Romeinse en die vroeë Germaanse reg ons leer.

Die algemeen gebruiklike manier waarop in die vroeë Romeinse reg ' $n$ regshandeling buite die hof plaasvind is per aes et libram, d.i. deur middel van 'n weegskaal en 'n stuk ongemunte koper, 'n skynkoop. So ken ons die mancipatio per aes et libram, ${ }^{16}$ ) 'n vorm van .eiendomsoordrag, die solutio per aes et libram, ${ }^{17}$ ) 'n vorm van ontheffing van 'n verpligting deur nakoming daarvan, die adoptio per aes et libram, ${ }^{18}$ ) 'n manier van aanneming tot kind, die testamentum per aes et lilram, ${ }^{19}$ ) 'n vorm van uiterste wilsbeskikking. Daar is nog ander ook.

Die manier waarop die handeling plaasvind blyk die duidelikste uit die tekste wat die mancipatio beskryf, die oordrag van die eiendomsreg op 'n stuk goed. Wat daarby opval is dat die handeling vormelik en plegtig van aard is. Naas die mancipatio ken die Romeinse reg ook nog 'n ander manier vir die oordrag van die eiendomsreg op 'n stuk goed, nl. die traditio. Dit is 'n veel minder omslagtige en minder plegtige handeling. In die latere reg het die traditio die mancipatio verdring. Oorspronklik egter, speel die traditio as manier van oordiag van eiendomsreg op goed slegs 'n rol by 'n sekere klas goedere, die res nec mancipi. Eiendomsreg oor goedere wat nie tot die klas behoort nie, die res mancipi, kan alleen deur mancipatio oorgedra word. Sonder die vorm wat voorgeskryf is, kan geen reg daarop na 'n ander party oorgaan nie. Indien die ander party hom sou laat oorhaal om sonder gebruikmaking van die voorgeskrewe vorm deur blote traditio die goed te ontvang, sou hy uitvind dat hy generlei reg daarop kan laat geld nie, dat hy dus niks verkry het nie, dat die eiendomsreg nog altyd by die oorspronklike eienaar is en dat hy dus op sand gebou het. Die vorm verskaf vir hom die sekerheid van oorgang van reg.

Tot die res mancipi behoort nou al die goed wat kenmerkend is vir die bedryf van die boer en waarvan ' $n$ mens sou veronderstel dat hy onder geen beding afstand wil doen nie. ${ }^{20}$ ) Die mancipatio per aes et libran is dus ' $n$ regshandeling waarby iets wat vir 'n persoon kenmerkend is teen die verwagting in aan ' $n$ ander afgestaan of oorgedra word; teen die verwagting in, omdat onder normale omstandighede hy die ding waarom dit gaan juis vir homself sal wil behou en daarvan geen afstand sal wil doen nie, want die afstand daarvan moet lei tot vermindering van sy kapasiteit om die werksaamheid wat hom kenmerk voort te sit. Die

16) GAI 'Institutiones I, 119 sq.

17) GAI III, 173 sq.

18) GAI I, 134 sq.

19) GAI II, 104 sq; Ulpianus, Regulae 20, 9.

20) Bechmann, Der Kauf nach gemeinem Recht, I, S. 147 e.v., aangehaal deur Hazewinkel-Suringar, Mancipatio en Traditio, bl. 26. 
vormlike, plegtige handeling is vereis om die voor die hand liggende veronderstelling dat die eienaar van sy goed geen afstand wil doen nie, doeltreffend te weerlé.

Die regshandeling per aes et libram as manier van oordrag van die eiendomsreg op goed is ' $n$ oer-oue instelling wat reeds ten tyde van die optekening van die Romeinse reg op die XII tabulae in 450 voor Christus bestaan. ${ }^{21}$ ) Wat by die verrigting van die negotium per aes et libram tref is, dat alhoewel twee partye aanwesig is en 'n reg van die een op die ander oorgaan, slegs een van die twee aktief optree en die ander 'n passiewe houding aanneem. ${ }^{23}$ )

Dieselfde eensydigheid van optrede vind ons ook by die Romeinsregtelike stipulatio, 'n regsinstelling wat in die $3 \mathrm{de}$ eeu voor Christus reeds bestaan. ${ }^{23}$ ) Dit is 'n vormelike manier om regsgeldige verbintenisse in die lewe te roep. Die partye moet daarby in mekaar se teenwoordigheid wees. Die een party formuleer mondeling die inhoud van die verpligting wat die ander party op hom moet neem. Die ander party antwoord met ' $n$ enkel woord daarop bevestigend. Dit blyk nie dat aan die ander party wat die verpligting op hom neem, enige invloed op die vasstelling van die inhoud van die verpligting toegeken word nie, net soos by die negotium per aes et libram een party eensydig verklaar wat sy reg ten opsigte van die stuk goed in kwessie is. Die ander party aanvaar daardie bewering wat gemaak word met stilswye ten aansien van die inhoud daarvan.

Terwyl by die genoemde regshandelinge die inhoud van die reël wat vir altwee partye geld eensydig, deur een van die partye alleen vasgestel word, soos vandag in ons reg die inhoud van 'n testament deur die erflater alleen vasgestel word, is aan die ander kant die feit dat die betreffende regshandeling plaasvind, afhanklik van die samewerking van altwee partye.

Dieselfde sien ons nou in die ou Romeinse reg gebeur ten aansien van die testament. ${ }^{24}$ ) Reeds in die 2 de eeu voor Christus kan dit deur 'n negotium per aes et libram tot stand kom. Daarby is die inhoud van die testamentêre beskikking van die erflater afkomstig en berus dit op sy wil. Maar om aan die wilsinhoud werking te verleen, is daadwerklike ooreenstemming met 'n ander party, die familiae emptor, vereis. Wat die erflater eensydig gewil het, kry kragtens die ooreenstemmende wil van die ander party tot uitvoering daarvan, effek.

'n Ooreenkomstige verskynsel vind ons in die ou Germaanse reg. Die Lex Salica (5de eeu na Christus), titel 49, bevat bepalings waarvolgens 'n erflater tydens sy lewe oor sy boedel of 'n deel daarvan ter

21) Tabula 6, 1; Girard, Manuel élémentaire de Droit Romain (1924) p. 298, n. 5; BuckLAND, Textbook of Roman Law, p. 236.

2a) Buckland, op. cit., p. 236; Hazewinkel-Suringar, op. cit., p. 44 sq.

23) GN III, 92 sq.

24) GAI II, 104. 
sake van sy dood kan beskik deur dit aan 'n vertrouensman oor te dra, wat dit ontvang met daardie doel. ${ }^{25}$ ) $\mathrm{Na}$ die dood van die erflater voer die vertroưensman die opdrag uit. Die wilsbeskikking van die erflater kom eensydig tot stand, maar die uitvoering daarvan berus op 'n ooreenkoms met die vertıouensman. Of die wilsbeskikking van die erflater uitgevoer sal word, hang af van die wilsooreenstemming tussen erflater en vertrouensman, dus ook van die vertrouensman. By die vasstelling van die inhoud van die wilsbeskikking, speel die vertrouensman egter geen rol nie. $\mathrm{Hy}$ is passief. Sy wil ten opsigte van die uitvoering word eers relevant na die etflater sy wil ten opsigte van die inhoud klaar bepaal het. Die twee wilsbesluite volg mekaar op in tyd, val nie saam nie. Sonder ' $n$ voorafgaande wilsbepaling van die erflater met betrekking tot die inhoud, is 'n met die erflater se wil ooreenstemmende wilsbesluit tot uitvoering daarvan aan die kant van die vertrouensman dan ook ondenkbaar.

Ook ons moderne reg ken die reëling waarvolgens die inhoud van 'n bepaling tot stand kom onafhanklik van die wil van die party wat daardeur gebind wil wees. Volgens arbeidsreg kan die inhoud van 'n arbeidsooreenkoms tot stand kom buite toedoen van die individuele arbeider om. Dit kan die resultaat wees van onderhandeling tussen en wilsooreenstemming van die werkgewer of 'n organisasie van werkgewers binne 'n bepaalde bedryf en velteenwoordigers van die georganiseerde werknemers. Tot vasstelling van die inhoud van sy verpligtings en regte onder die kontrak, lewer die individuele werknemer geen bydrae nie; dit gaan volkome buite hom om. Sy ekonomiese posisie is van so'n aard dat hy alleen tog nie by magte is om enige invloed uit te oefen nie. Al wat vir hom oorbly om te doen is om na totstandkoming van die inhoud van die ooreenkoms, wat homself betref te oorweeg en te besluit of hy bereid is om die kontrak wat aldus tot stand gekom het, te aanvaar. Indien hy wil werk is in die praktyk in so'n geval van 'n eie vrye keuse om te verwerp nie eintlik sprake nie. Die omstandighede dwing hom dan om te aanvaar. Die keuse lê nie tussen voor of teen die bepalings van die kontrak nie, maar tussen werk volgens die bepalings van die kontrak of geen werk nie.

In die Volkereg het hierdie figuur sinds die vorige wêreldoorlog meer en meer in swang geraak. Die Kellogg-Briand-verdrag van 1928, die sogenaamde Pakt van Parys, is 'n ooreenkoms, verdrag of verbond, waarvan die inhoud deur middel van onderhandeling tussen die verteenwoordigers van 'n paar state (Verenigde State van Amerika, Frankryk, Engeland, Duitsland, Italië en Japan ${ }^{26}$ ) tot stand gekom het. Dit is op 27 Augustus 1928 te Parys deur verteenwoordigers van 15 state geteken

35) Corpus Juris Germanici Antiqui (HeIneccius, 1738), p. 99.

26) België, Pole, Tsjeggo-Slowakye, Kanada, Ierland, Australië, Suid-Afrika, NuSeeland en Brits-Indië is ook geraadpleeg; Lysen, Le Pacte Kellogg; KreIntjes, Inleiding tot het Volkenrecht (1936), bl. 199. 
en het vervolgens regskrag verkry. Verteenwoordigers van ander state ${ }^{27}$ ) was by die onderhandeling nie betrokke en is nie in die geleentheid gestel om invloed op die uitslag uit te oefen of aan die ondertekening deel te neem nie. Die hoofbepaling van die verdrag is die verwerping van oorlog as 'n werktuig van nasionale politiek in die betrekkinge van state onderling. In die verdrag kom ook 'n klousule voor waarby aan ander state die geleentheid gegee word om hulle daarby aan te sluit. Meer as 45 ander state het dit vervolgens gedoen. Maar deur te besluit om tot die verdrag toe te tree en dit daarmee op hulle van toepassing te maak, het hulle op die inhoud daarvan, wat reeds buite hulle om tot stand gekom het, tog nie die minste invloed kon uitoefen nie. Hul instemming was nodig om 'n regtens bestaande norm, ook ten opsigte van hulle te laat werk. Sonder hul instemming het die norm reeds tot stand gekom en gewerk. Hul handeling van toestemming het betekenis gehad vir die gelding van die norm ten opsigte van hulle ook, nie op die ontstaan of die voortbestaan daarvan nie.

In die lig van wat voorafgaan kan ons sê dat wanneer diathêkê met ,testament' vertaal word en dus as 'n eensydige regshandeling opgevat word, die vertaler klem lê op die feit dat die inhoud van die bepaling deur een party alleen, in die verband van die Ou en die Nuwe Testament deur God, vasgestel is. Wanneer daarenteen diathêkê met ,verbond' vertaal word en dus as 'n tweesydige reghandeling opgevat word, lê die vertaler klem op die feit dat die eensydig deur God vasgestelde inhoud van die bepaling deur die ander party, die mens, die volk van God, as vir hom geldend aanvaar is of moet word.

Diathêkê en sunthêkê word wel identiek verklaar. In wese behoort die twee begrippe wat daardeur benoem word, tot twee verskillende kategorieë. Sunthêkê behoort tot die sfeer van die outonomie van die partye, die gebied van die neweskikking, van gelykheid, van onafhanklikheid van mekaar. Diathêkê behoort tot die sfeer van die heteronomie, waar die een party buite die ander party om die norm vasstel, wat die ander party kragtens sy daaropvolgende wilsbesluit moet bind; dit dui op ondergeskiktheid van die een aan die ander, dit veronderstel ongelykheid, afhanklikheid; die inisiatief lê daarby aan een kant alleen. In ons verband beteken dit dat God beskik, en dat die mens aanvaar of verwerp wat $\mathrm{Hy}$ beskik het en die beskikking nie kan beïnvloed nie

D. PONT

27) bv. Nederland, Rusland. 